\author{
Shumenko O.A., \\ Candidate of Philological Sciences, \\ Associate Professor of Germand Depatment \\ Sumy State University
}

\author{
Kashenko P. V., \\ Bachelor Student of Germand Depatment \\ Sumy State University
}

\title{
STRUCTURAL SEMANTIC PECULIARITIES OF LEGAL TERMS IN THE ENGLISH LANGUAGE
}

Summary. The article is devoted to sociological and cultural aspects of the English-speaking environment as extra-linguistic factors of the text organization in the field of jurisprudence. In the field of our study there were peculiarities of the ways of translation and reproduction of cultural and social phenomena in Ukrainian translations of English legal literature. The article focuses on the cultural and sociological aspects of the translation of legal literature and on examples of original texts in English jurisprudence, which the translator must pass on all the peculiarities of the culture of the language of the native speaker.

The urgency of the topic is due to the fact that today the question of considering the language in terms of its interaction with culture and society are, on the one hand, not enough and common, and, on the other hand, the fact that the translation of sectoral texts is precisely in terms of their correlation with cultural and sociological aspects of life are an important issue of translation activity.

All terms are combined into terminology systems that express the concept of one branch of knowledge. In each terminology system, certain groups are formed, for which their general membership belongs to a class of objects, or to a class of processes, properties, etc.

The results of this study will show that the problems of the functioning of legal terminology are of further interest in various aspects: linguistic, discourse, social, legal. It is expedient to study other aspects of the functioning of legal terminology, in particular in historical discourse (texts on history), regional studies, sociocultural and environmental. These questions, from the perspective of linguistics, cognitive linguistics, discourse and stylistics, can be the subject of future research.

Key words: jurisprudence, legal literature, legal terminology, economic / legal discourse, legal semantics.

Determination of the emotionally-subjective nature evaluation of terminology, its language-stylistic signs is the one from the main problems of business language linguistic. This issue, to the same extant, is essential and for problems of developing the scientific language style due to penetration emotional elements into it and their possibility to coexist with elements of logical.

The theme topicality is due to the fact that today the language review issue in aspect of interaction with culture and society is, on the one hand, insufficiently distributed and uncovered and, on the other hand, that, what the translation branch texts in terms of their correlation with the cultural and sociological aspects of life is an important issue of translation activity.
The object is the sociological and cultural aspects of the English-speaking environment as extra-linguistic factors of a text organization in the field of jurisprudence. The subject is the peculiarities of translation strategies in the methods of reproduction of cultural and social phenomena found in Ukrainian translations of English legal literature.

The aim is to reveal the cultural and sociological aspects of the translation of legal literature, and to illustrate, with the help of the original texts in English jurisprudence, by means of which the interpreter must pass all the peculiarities of the language of the language of the native speaker into the language of translation. The realization of this goal involves solving the following tasks:

- characterize the main problems of translation, connected with the specifics of cultural and social phenomena, which are directly reflected in the language of the people;

- clarify the definition of the phenomenon of translation of legal literature and characterize its features;

- determine which cultural and sociological aspects should be taken into account when translating texts from jurisprudence;

- to name the main methods of translation of legal texts taking into account their socio-cultural features;

- on the basis of concrete examples, show translation problems related to cultural and sociological aspects.

English terminological legal vocabulary was formed for centuries. This terminology system continues to evolve, constantly changing, but at the same time it is a single, integrated system that functions and varies with human society.

The question of the genesis of the English legal terms used in the legal discourse is specific; it has not yet been considered and in this work is being investigated for the first time. We would like to emphasize that borrowing from the legal terminology of legal termoelements is conditioned primarily by social processes, inter-social relations and economic development of the state. Constant economic and legal progress requires a legal status in the implementation of economic relations. Therefore, we increasingly note the functioning of legal terminology in the economic subcategory. Attention is drawn to the fact that the process of "entering" legal terminology in the language of various spheres dates back to the Middle Ages, when the legal and economic relations between certain social groups began to emerge. Consider diachronic the issue of genetic legal transpositions. The analysis of literature on this issue has shown that the transformation and transposition of legal terms in multi-language texts is a natural 
phenomenon, resulting from the inheritance of the vocabulary of some generations as follows. At the same time, a combination of the old and the actualization of the new vocabulary is carried out by scientists, lawyers, economists and other groups of the population directly dealing with legal, economic activity.

Elements of the legal terminology system, its forms and models originate from the English socio-legal lexicon of the Middle Ages. At further stages of historical development there is an expansion of semantics of commonly used social and economic systems on the basis of corresponding scientific definitions. Moreover, the words that preserved root morpheme for centuries continue to acquire the possibility of diverse derivation, in particular, they can be made by other suffixes, without losing most of their original meaning. Analyzing the factual material, we came to the conclusion that legal terms of legal discourse should be differentiated according to the origin of their foundations. These are terms that are selfspeaking words (group 1); having a Latin (group 2) and a French (group 3) basis. To group 1 we classified the following terms: deed, sale, settlor, share, strike, etc. ( $4 \%$ of the total number of words recorded). Group 2 - acceleration, alienation, contract, license, premium and others (the largest among groups, $82 \%$ of terms). Group 3 contains the following elements: abandon, abatement, allotment, sabotage, etc. (14\% of all legal terms of economic discourse). At the same time, we recorded a double borrowing of most terms with the Latin base, which came to English through Old French. All this can be displayed schematically in the following way:

Table 1

Types of the basis of the legal terminology of origin

\begin{tabular}{|c|l|c|c|}
\hline № & \multicolumn{1}{|c|}{ Legal terms } & Frequency of use in $\%$ & $\begin{array}{c}\text { Frequency of use } \\
\text { (in absolute numbers) }\end{array}$ \\
\hline 1 & Spoken words & $4 \%$ & 4 \\
\hline 2 & Latin borrowing & $82 \%$ & 82 \\
\hline 3 & French borrowing & $14 \%$ & 14 \\
\hline \multicolumn{2}{|l|}{ Together } & $100 \%$ & 100 \\
\hline
\end{tabular}

Semantics and semantic evolution are devoted to a number of works, including F. Palmer, V. Ovcharenko, R. Tsagolova, O. Vakulova, G. Klychkov, and others. Questions of the study of legal and economic terminology were considered mainly within the framework of structural-semantic analysis, in the system of relevant discourse - economic terminology in economic discourse, legal - in legal, etc. The problem of the functioning of legal terminology in economic discourse, as well as the semantic field of legal terminology in the structure of economic discourse.

In connection with the defined research methodology, it is important to consider semantic fields, in particular, the level (degree) of their terminology. You can consider semantic fields by the degree of terminology or the degree of storage of semantic value in a specific field of specialization, as well as the pragmatics of the context. In economic discourse, the legal term may retain its value, in whole or in part, or completely lose it.

Note that under the influence of interference, when entering into the legal framework, legal terms pass the so-called specialization, changing its place in the system, definitions. They can be converted into homonyms or are homonyms of the original terms. For example, the term eng. - liability - ukr. - осудність, відповідальність, зобов'язання in the legal terminology system are a homonym for the economic term eng. - liability (in plural) - ukr. - nacuв.
After analyzing the legal literature of various genres and using lexicographic economic and legal dictionaries, we found that approximately $73 \%$ of all legal terms of legal discourse became an integral part of the legal status due to their productive use in the field of legal activity and the legal status of business operations . At the same time, these elements in the process of transmission in the legal terminology system is entirely of legal significance. These are the following terms: eng. - acceptance - ukr. - акцепт; eng. bond - ukr. - бона, купюра, облігація; eng. - credit - ukr. - кредит; eng. - creditor - ukr. - кредитор; eng. - employment - ukr. - зайнятість; eng. - tax - ukr. - податок; eng. - mortgage - ukr. - застава, іпотека; eng. - rent - ukr. - рента; eng. - share - ukr. - акція, пайова участь, eng. - patent - ukr. - патент, etc.

The analysis of legal terminology from the perspective of the presence or loss of primitive semantics, conducted on the basis of multi-genre discourse, showed that the vast majority of legal terms retain their main semantics (capacity, term, contract, court, tax, fraud, valid, breachofcontract, incometax, etc.). 99.6\% of terms correspond to semantics in the field of legal texts, can partially realize the value of a legal term $0.2 \%$ of terms. There is also the desemation of the mentioned terms in the structure of the economic text $(0.2 \%$ of the terms). We also recorded cases in which, simultaneously in different legal contexts, term terms of a legal terminology system can retain legal semantics, partially implement it and fully preserve it. We have fixed these terms two: valid, capacity.

\section{Table 2}

Preservation of the original semantics of the legal term

\begin{tabular}{|c|l|c|c|}
\hline № & Semantic sign of terms & Frequency of use in \% & $\begin{array}{c}\text { Frequency of use } \\
\text { (in absolute numbers) }\end{array}$ \\
\hline 1 & $\begin{array}{l}\text { Legal terms that retain } \\
\text { their semantics }\end{array}$ & $74 \%$ & 74 \\
\hline 2 & $\begin{array}{l}\text { Terms that correspond } \\
\text { to semantics in the } \\
\text { field of legal texts }\end{array}$ & $16 \%$ & 16 \\
\hline 3 & $\begin{array}{l}\text { Terms that partially } \\
\text { realize the meaning } \\
\text { of a legal term }\end{array}$ & $10 \%$ & 10 \\
\hline Together & $100 \%$ & 100 \\
\hline
\end{tabular}

Consequently, the largest number of terms retaining their semantics are legal terms that fully preserve their legal semantics ( $74 \%$ and 74 terms of the entire legal terminology), the second on the list - terms that correspond to semantics in the field of legal texts (they are counted $-16 \%$ and 16 terms of the entire legal terminology), and the latter group - the terms that partly realize the value of a legal term - are the smallest in the frequency of use (they make up 10\% and 10 terms in the legal terminology system).

It should be noted that the terms of various branches of science in the process of development and modification of languages tend to interfere with the integration of sciences. Sectoral terminology interacting with each other often has a part of the common terminology fund. Migration of terminological elements leads to such phenomena as transterminalization, determinism, differentiation of values, reterminologization, and the like. This is possible when the subject of one branch of science absorbs the terms of another. As a dynamic phenomenon, migration causes quantitative (in the form of new nominative units) and qualitative (new meanings) of the enrichment of a certain vocabulary at the level of speech: 
through the mass media, popular science and fiction. As a static phenomenon, migration determines the quantitative and qualitative enrichment of the vocabulary of a certain layer of language at the system level.

There are basic methods of translation of terms that require knowledge of the field concerned with translation, understanding the content of terms in English and knowledge of terminology in the native language. When translating legal literature, the interaction of the term with the context is important, which makes the meaning of the word manifest. A. Ya. Kovalenko defines two stages in the translation process of the term: the first is to find out the meaning of the term in the context, and the second is to translate into the native language.

The main method of translation of terms is translation using the lexical equivalent. The equivalent is a constant lexical match that exactly matches the meaning of the word. Terms that have equivalents in their native language play an important role in translating. They serve as reference points in the text, from which the disclosure of the meaning of other words depends on them, they give an opportunity to find out the nature of the text. Therefore, one should be able to find the corresponding equivalent in the native language and extend knowledge of the terms-equivalents.

All terms in their structure A. Ya. Kovalenko divides into:

- Simple, consisting of one word: eng. - attorney - ukr. - npoкурор;

- complex, consisting of two words and written together or through a hyphen: eng. - jurisprudence - ukr. - юриспруденuіiя;

- phrases, which consist of several components: eng. - federal court jurisdiction - ukr. - юрисдикиія федерального суду.

Terms-phrases are divided into three types. The first type includes terms-phrases, the components of which are independent words, which can be used separately and retain their meaning: eng. - law, faculty, franchise, freedom, liberty, power - ukr. - nраво; eng. - amortization, killing, criminal homicide, unlawful homicide, homicide, murderment, slaughter, blood, bloodshed - ukr. - вбивство. The second type includes such terms-phrases, which have one of the components of a technical term, and the second a commonly used vocabulary. Components of this type can be two nouns, or nouns and adjectives. This method of creating scientific and technical terms is more productive than the first, where two components are independent terms: eng. - negligent killing, negligent homicide, negligent manslaughter - uk. - вбивство через необережність. The third type includes terms-phrases, both components of which are words commonly used vocabulary, and only the combination of these words is a term. This way of creating scientific and technical terms is unproductive: eng. adjudicatory jurisdiction - ukr. - вирішення судових справ.

Table 3

Types of phrases in legal terminology

\begin{tabular}{|c|l|c|c|}
\hline$№$ & Type of term - phrase & Frequency of use in \% & $\begin{array}{c}\text { Frequency of use } \\
\text { (in absolute numbers) }\end{array}$ \\
\hline 1 & Independent terms & $75 \%$ & 75 \\
\hline 2 & Intermediate terms & $15 \%$ & 15 \\
\hline 3 & General terms & $10 \%$ & 10 \\
\hline \multicolumn{2}{|c|}{ Together } & $100 \%$ & 100 \\
\hline
\end{tabular}

Consequently, in the legal terminology of the English language, terms are often used, the components of which are independent words that can be used separately and that retain their meaning ( $75 \%$ and 75 terms of the entire terminology system), slightly less used phrases, which have one of the components technical term, and the second commonly used vocabulary. (15\% of the terms and 15 terms of the legal terminology), and the least use of the termsphrases, both components of which are words commonly used vocabulary, and only the combination of these words is a term. ( $10 \%$ terms and 10 terms of the entire legal terminology).

All terms are combined into terminology systems that express the concept of one branch of knowledge. In each terminology system, certain groups are formed, for which their general membership belongs to a class of objects, or to a class of processes, properties, etc.

The results of the study indicate that the problems of the functioning of legal terminology are of further interest in various aspects: linguistic, discourse, social, legal. It is expedient to study other aspects of the functioning of legal terminology, in particular in historical discourse (texts on history), regional studies, sociocultural and environmental. These questions, from the perspective of linguistics, cognitive linguistics, discourse and stylistics, can be the subject of future research.

References:
1. них стандартів Мова і духовність націй. Київ, 1992.

2. Гумовська I.М. Англійська юридична термінологія в економічних текстах: генезис, дериваційні та семантико-функціональні аспекти : автореф. дис. канд. філол. наук: 10.02.04 ; Львів. нац. ун-т ім. І. Франка. Львів, 2000.

3. Дерді Е.Т. Юридичні терміни-композити в англійській мові. Мовні і концептуальні картини світу. Київ, 2000. 470 с.

4. Иртеньєва Н.С. Іншомовні слова в сучасній юридичній термінології Мова і культура наиії : зб. наукових праць. Львів, 2001.

5. Клименко Л.В. Паронімія в юридичних сентенціях англійської мови. Проблеми семантики слова, речення та тексту : зб. наук. $n p$. Київ : Вид. центр КНЛУ, 2001. Випуск 7.

6. Клименко Л.В. Семіотичні аспекти юридичних сентенцій англійської мови. Мовні і концептуальні картини світу : зб. наук. пр. Київ : Прайм-М, 2002. Випуск 6. Книга 1.

7. Клименко Л.В. Утвердження юридичного статусу англійської мови Мовні і концептуальні картини світу : зб. наук. пр. Київ : Логос, 2000.

8. Клименко Л.В. Сталі словосполучення в юридичній мові. Наукова спадщина професора Ю.О. Жлуктенка та сучасне мовознавство : зб. наук. пр. Київ : Логос, 2000.

9. Сергєєва Г.А. Англомовні запозичення в українській правничій термінології : автореф. дис. канд. філол. наук : 10.02 .01 ; Харк. нац. ун-т ім. В.Н. Каразіна. Харків, 2002. 370 с.

10. Снігур С. Юридичні терміни як перекладознавча проблема. Bicник. Львів, 2003. № 490: Проблеми української термінології. 570 с.

11. Ушакова М.Б. Українське термінознавство на сучасному етапі Український правопис і наукова термінологія: проблеми норми і сучасність: Матеріали мовознавчої комісії НТШ. Львів, 1997. C.101-108.

Шуменко О. А., Кашенко П. В. Структурносемантичні особливості юридичних термінів В англійській мові

Анотація. Стаття присвячена соціологічним та культурним аспектам англомовного середовища як позалінгвістичним факторам організації тексту в галузі юриспруденції. У галузі нашого дослідження виявились особливості способів перекладу та відтворення 
культурних та соціальних явищ в українських перекладах англійської юридичної літератури. Стаття зосереджується на культурних та соціологічних аспектах перекладу юридичної літератури та на прикладах оригінальних текстів з англійської юриспруденції, якими перекладач повинен передати всі особливості культури мови носія мови.

Актуальність теми зумовлена тим, що сьогодні питання розгляду мови 3 точки зору іï взаємодії 3 культурою та суспільством, $з$ одного боку, недостатньо поширене, а 3 іншого - тим, що переклад галузевих текстів саме з точки зору їх співвідношення 3 культурними та соціологічними аспектами життя є важливим питанням перекладацької діяльності.

Усі терміни об'єднані в термінологічні системи, що виражають поняття однієї галузі знання. У кожній термінологічній системі формуються певні групи, до яких їx загальна належність належить до класу об'єктів або до класу процесів, властивостей тощо.

Результати цього дослідження покажуть, що проблеми функціонування юридичної термінології представляють додатковий інтерес у різних аспектах: мовному, дискурсному, соціальному, юридичному. Доцільно вивчити інші аспекти функціонування юридичної термінології, зокрема в історичному дискурсі (тексти 3 історіі), краєзнавстві, соціокультурному та екологічному. Ці питання з погляду мовознавства, когнітивної лінгвістики, дискурсу та стилістики можуть стати предметом подальших досліджень.

Ключові слова: юриспруденція, юридична література, юридична термінологія, економічний/юридичний дискурс, юридична семантика. 